\title{
The Effectiveness of
}

Monetary Transmission

Channels: The Case of

Central and Eastern

European Transition

Economies

\section{Dr. Fatma Gündoğdu Odabaşığlu}

Ataturk University

Dr. Celil Aydın

Muş Alparslan University

\begin{abstract}
Many factors including government actions, the depth of financial markets, the structure of banking sector, capital movements, etc. affect the functioning of the monetary transmission mechanism. Thus, the determination of the channels playing an active role in the transmission mechanism is of vital importance for making policy decisions aimed at ensuring price stability. The present study aimed at investigating the effectiveness of the monetary transmission channels in Central and Eastern European (MDA) transition economies. In this regard, the study tested the effects of the monetary transmission channels in MDA transition economies in the 1995:01-2012:12 period on macroeconomic variables. Firstly, the Vector Autoregression Analysis (VAR) was carried out in order to determine the short-term dynamics of the effects of the transmission channels on macroeconomic variables. Secondly, the long-term dynamics of the effects of transmission channels on macroeconomic variables were searched via autoregressive distributed lag (ARDL) analysis. It was concluded in study that financial development and exchange rate were the most efficient channels on economic variables in most of the said economies.
\end{abstract}

Keywords: Monetary Transmission Channels, VAR Analysis, ARDL Approach. 


\section{INTRODUCTION}

The concept of transition economy is generally used for referring to those economies which transited from central planning to market economy as the Berlin Wall came down in 1989 and the Soviet Union dissolved in 1991. Transition from a centrally planned economy to market economy has required important institutional and structural reforms in fields such as liberalization of prices, exchange, and trade, small-scale and large-scale privatization, banking sector, and nonbank financial institutions. In this regard, shock therapy or gradualism began to be implemented in economies between 1990 and 1992 in general. The speed at which the reforms were implemented and the degree to which they were put into practice effectively and comprehensively varied from country to country depending on the geographical, social, political, and economies conditions prevalent at the start time of transition as well as the strategy adopted (Svejnar, 2002, pp. 3-7). The CEE countries such as Poland, Bulgaria, Slovakia, Estonia, Latvia, the Czech Republic, and Romania applied shock therapy while other countries adopted gradualism. The CEE countries made a great progress in transition to market economy, and most of these countries became a member of the European Union by completing the transition period successfully. Poland, the Czech Republic, Hungary, Slovenia, Slovakia, and the Baltic states (Estonia, Lithuania, Latvia) became a member of the European Union in 2004 while Romania and Bulgaria became a member of it in 2007. Croatia and Macedonia applied for membership to the EU in 2003 and 2004 respectively. Then they were accepted as members. Albania applied for membership to the EU in 2009, but it has not been accepted yet. Among the countries which are in the Eurozone and have adopted a single currency are Slovenia (2007), Slovakia (2009), Estonia (2011), and Latvia (2014).

Fluctuations in total product and inflation experienced in CEE economies in transition period and economic instability conditions accompanying them increased the importance of the policies to be implemented by economic policy decision-makers. The degree to which monetary policy decisions influenced inflation and economic activity through the medium of different channels determined the effectiveness of such policies. In this respect, the present study aims to determine the efficiency of monetary transmission channels in CEE transition economies. 
This paper firstly presents short theoretical information and literature review on the functioning of transmission channels. In the experimental part, VAR analysis is made in order to identify the short-term dynamics of the influences of transmission channels on macroeconomic variables in CEE transmission economies on the basis of the data of the World Bank and the IMF belonging to the period between 1995:01 and 2012:12. Thenthe long-term dynamics of the influences of each transmission channel on these macroeconomic variables are investigated via ARDL method. The study involves the interest rate, exchange rate, and credit channels which are generally accepted and frequently handled in literature as well as the financial development channel, which is included in the present study to see the role played by financial development levels in the transmission mechanism in the examined economies.

It is easy to observe that monetary transmission channels do not work independently of each other, and sounder results are obtained in the assessment of the efficiency of the transmission mechanism of an economy when the influences of all channels including those channels which arise from other channels are analyzed together. A limitation of the present study, on the other hand, is that such analysis is made in this paper only as an article, and thus only the interest rate, exchange rate, credit, and financial development channels are focused on. Another limitation of the study is that those CEE countries which are not member of the European Union are not included in analysis because of the problems in obtaining data.

\section{MONETARY TRANSMISSION CHANNELS}

Monetary policy refers to the decisions made by monetary authorities to ensure price stability by use of various instruments while monetary transmission mechanism refers to the effect of these decisions on economic activity and inflation through the channels of interest, exchange rate, asset prices, and expectations. It is transmission mechanism between money market and real market which is the most important factor influential on the efficiency of monetary policy in economies. Changes in the money market of a country as a result of the conditions undergone by its economy affect its real sector through various channels (Kuttner and Mosser, 2002, 
pp. 15-16). Summary information is provided below about such generally accepted channels of monetary transmission mechanism as interest rate, exchange rate, and credit as well as the financial development channel included in the present study as distinct from relevant literature.

\subsection{The Interest Rate Channel}

According to Keynesian view, a fall in real interest rate due to monetary expansion decreases cost of capital, thereby leading to an increase in investments and thus in total product (Dornbusch and Fischer, 1994, pp.125-127). Though Keynes explains the functioning of the interest rate channel based on the way companies' investment decisions are affected, applied research shows that monetary authorities affect consumers' cash flows and consumption decisions and producers' investment and spending decisions by changing real interest rates and thus can change total demand in an economy. The fact that it is not the nominal interest rate but the real interest rate which influences expenditures points to a mechanism where monetary policy is influential on real economy even during periods of deflation when the nominal interest rate falls too much. This is because; even if the nominal interest rate is zero, an increase in supply of money may increase expected prices and thus anticipated inflation.

As a result, spending may be encouraged with the real interest rate going down. Additionally, it is not the short-term real interest rate but the long-term real interest rate which is influential on expenditures (Mishkin, 2007, pp. 584-590). By the functioning of the interest rate channel, a change starting in the short-term interest rate manifests itself in medium-term and long-term interest

Inquipy $2015 / 2$ rates through supply-demand mechanism in financial markets. In other words, the change made by the monetary authority in the short-term nominal interest rate influences the short-term and the long-term real interest rates under the assumption of price rigidity (sticky prices) ${ }^{1}$. Price rigidity is one of the factors making monetary

(1)New Keynesian approaches assume that prices cannot be changed immediately, but are adjusted gradually after a fluctuation in economy. Nominal price rigidity means that when companies change the prices of their goods and services, they have to face certain costs, menu (transaction) costs being in the first place, and these small costs may bring a big and permanent fluctuation to economy. In new Keynesian approaches, real price rigidity is grounded on setting the sale prices of goods and services by adding a particular rate of profit to their costs, and it is of great importance in that it shows the real effect of nominal rigidity. Among other reasons for real price rigidity are market externality, consumer markets, and capital market distortions (For detailed information see Sariipek and Kesici, 2010, pp. 26-34). 
policy influential on real economy in the short term. The degree of rigidity determines how long it takes for monetary transmission to take place (Taylor, 1999, pp. 1036-1038).

\subsection{The Exchange Rate Channel}

Changes in exchange rate lead to a change in relative prices of goods in national and international markets and thus in total demand, production, and prices (Faini, de Melo, 1990, pp. 498-500). When interest rates are changed, monetary policies implemented in an environment where international capital movements have liberalized to a great degree have considerable influences on exchange rate (Sandte, 1999, pp. 175-181). Changes in interest rates change exchange rate by affecting the volume of international capital movements and thus the value of national currency. In an economy which is in a net debtor position, interest and dividend payments made in foreign currency decrease income and thus affect total demand negatively as a result of income effect.

When a contractionary monetary policy is implemented, interest rates and capital inflow increase. As a result, exchange rate goes down, and national currency rises in value. When national currency rises in value, export becomes more expensive; import becomes cheaper; competitiveness in domestic industry decreases; and export and production go down (Taylor 1993, pp. 270-272).

Exchange rate may affect production and total demand over income and wealth, too. Income and wealth effect is mostly observed in developing economies where borrowing is in foreign currency to a great degree. When an expansionary monetary policy is implemented, foreign currencies rise in value against the national currency, and thus the debt burden of enterprises increases. However, as no change occurs in the value of the assets of an enterprise assessed in the national currency while its net value goes down, a decrease takes place in the amount of loan acquired depending on adverse selection and moral hazard problems and thus its investment.

On the other hand, distinction between nominal and real exchange rates is important in the analysis of the economic effects of changes in exchange rates. This is because; rise in nominal 
exchange rates causes a rise also in real exchange rates in the short term due to price and wage rigidity (Taylor, 1995, p. 16).

\subsection{The Credit Channel}

The implementation of an expansionary monetary policy results in an increase in the amount of deposits of banks, the amount of the reserves they can supply as credit, and thus the amount of the credit they extend. Such increase in the amount of credit raises enterprises' investments and thus total demand. Furthermore, expansionary monetary policy may also put share prices up thereby raising the values and the cash flows of enterprises. In such a case, an increase may occur in the credit supply of banks. What's more, the importance of the role played by the bank credit channel inthetransmission mechanism becomes clearer when banks compensate the fall in their reserves resulting from contractionary monetary policy by reducing their supply rather than selling securities (Bernanke and Gertler, 1995, p. 29).

On the other hand, the changes to be created by monetary policy alterations in the balance sheets of enterprises can be explained over the balance sheet channel, which is another sphere of influence of the credit channel. The implementation of a contractionary monetary policy increases the cost of business liabilities and decreases the value of long-term assets. In this way, the capital costs of enterprises go up. However, the credit channel influences the investment expenditures of small-scale and mediumscale enterprises (rather than large-scale enterprises) that are incapable of meeting their funding needs from money and capital markets and are dependent on bank credits.

\subsection{The Financial Development Channel}

Increase in the number and diversity of financial institutions as a result of financial liberalization causes financial development. Financial development refers to the generalization of channels that turn savings into investment in the process of financial innovation in an economy. In an economy with a low financial development level, the banking system has a high cost and high profit oligopolistic structure, and monetary flows mostly head for unorganized markets. In such markets, transactions are carried out in the short term 
due to legal pressures and the high nonpayment risk of borrowed funds. A structure of this sort reduces the efficiency of the monetary transmission mechanism. It may also bring about a lack of long-term markets, more change in short-term interest rates, and thus high volatility in interest rates (Fraga, Goldfajn, and Minella,2003, pp. 388-389).

On the other hand, in literature, the depth of financial markets is regarded as a prerequisite for a successful inflation targeting regime and plays an important role in the implementation of the monetary policy by use of market-based instruments. Any weakness in these markets makes the implementation of the monetary policy difficult, and any problem experienced in funds for private sector investments creates pressure on borrowing costs (Stone, 2003, p. 5). A financial system deepens and develops to the extent that it can transfer the funds created in the financial sector to the real sector. If a financial system does not deepen enough, the funds created in it remain there and turn into financial gain, and failure in financing real sector investments has a negative influence on total product in the longterm (Öztürk, Barışık, and Darıcı, 2010, p. 98).

\section{LITERATURE REVIEW}

The structure and functioning of the monetary transmission mechanisms varies by country due to the structure and depth of financial systems, the share of the public sector in economy, openness of economies, changes in economic structure on local and global levels, and so on (The Central Bank of the Republic of Turkey, 2013, p. 1). Literature contains a lot of studies dealing with the transmission mechanisms in various countries or groups of country in which the influences of monetary policy decisions on real sector variables are investigated in terms of just one channel or several channels. In this regard, some of the studies dealing with the functioning of monetary transmission channels in CEE transition economies based on comparative analysis are described below in summary. Mostly, VAR model has been used in these studies. Jarocinski (2004), Creel and Levasseur (2005), Anzuini and Levy (2007), and Oros and Turcu (2009) employed VAR model.

Ganev et al. (2002) investigated the efficiency of the interest rate and exchange rate channels in all EU member CEE transition economies in the period between 1995 and 2000 period through the 
Granger causality test and impulse response analyses and tried to reveal the existence of long-term relationships between basic macro variables. They analyzed impulse response functions shedding light on the response of industrial production and inflation to changes in interest rate and exchange rate taken into consideration as basic policy surprises. They concluded that there is a systematic interaction between the variables in the long term for all countries except for Estonia and Slovenia, and inflation responses are mostly consistent with the theory for transition economies (e.g. decrease in case of rise in interest rate, and increase in case of fall in exchange rate).

Jarocinski (2004) aimed to predict the responses to monetary shocks in the economies of the Czech Republic, Hungary, Poland, and Slovenia between 1990 and 2004, used Bayesian method, and concluded that the sensitivity of monetary policy is low in these economies, and price responses to monetary shocks occur with more delay.

Creel and Levasseur (2005) carried out a study on the Czech Republic, Hungary, and Poland covering the period between 1993 and 2004 and investigated the functionality of the interest rate, exchange rate, and credit channels in their economies. They concluded that prices increase, but not decrease as a result of sudden loss in value in the nominal exchange rate after an upward shock to the interest rate in all of these countries and explained it with exchange rate and price puzzle ${ }^{2}$. They observed that the interest rate, exchange rate, and credit channels were not very efficient in the functioning of monetary transmission mechanisms, and the exchange rate and interest rate channels played an increasing role in Poland relative to other countries subject to comparison lately.

Elbourne and Haan (2006) evaluated the functioning 2015/2 of monetary transmission mechanisms in all EU member CEE countries through taking different sample periods for each country on the basis of monetary policy regime between 1993 and 2004. They took the size, concentration, and strength of banking sector as well as the usability of alternative financial instruments as the financial structure indicators of countries and concluded that the mechanism

(2)It was concluded in analyses in which the New Open Macro-economy models were applied that international macroeconomic problems lead to different puzzles. One of them is the relationship between exchange rate and imported product prices. It was stated that imported product prices affect global expenditures over exchange rate (Landry, 2009, pp. 60-61). 
would function efficiently if weak banks were strengthened.

Hericourt and Matei (2007) divided the analysis period from 1995 to 2004 into sub-periods involving the stable currency regimes of countries for CEE countries joining the European Union in2004 (Slovenia, Slovakia, Estonia, Lithuania, Latvia, Poland, the Czech Republic, and Hungary). They concluded that the positive interest rate shock triggered substantial falls in the entire industrial production and price and exchange rate puzzle did not emerge in each one of CEE countries except for Hungary in analyses corresponding to steady currency regime periods and covering shorter periods to the contrary of the results obtained from analyses covering all periods. They noted that the functioning of monetary policy transmission mechanism in these countries was close to the one in the Eurozone countries thanks to the important role played by the interest rate channel.

Anzuini and Levy (2007) aimed to determine the influences of monetary policy shocks in the Czech Republic, Hungary, and Poland between 1993 and 2002 and obtained similar results to the those European countries which were better in terms of financial development.

Oros and Romocea-Turcu (2009) aimed to reveal the relative importance of the interest rate, exchange rate, and domestic credit channels linked with currency regimes for the functioning ofthemonetary transmission mechanism in Hungary, Poland, the Czech Republic, Romania, Slovakia, and Slovenia between 1998 and 2007 and summarized the results they obtained as follows: the relative efficiency of the interest rate and exchange rate channels varied from country to country. However, the domestic credit channel played a weak role in all countries. In Hungary and Poland, there was a price puzzle associated with the exchange rate transmission channel that both absorbed the supply-demand shocks and had high efficiency in in terms of functioning. In addition, the interest rate channel had an important influence in the Czech Republic, Slovakia, Slovenia, and partly Romania.

Matousek and Sarantis (2009) tested the efficiency of the bank credit channel for eight EU member CEE economies in the period between 1994 and 2003 via panel and dynamic panel data analysis

Inquipy

$2015 / 2$ 
and concluded that the credit channel was efficient in all countries in general. Moreover, they found out that size and liquidity structure played an important role in in the variation of responses of banks to changes in monetary policy.

Jimborean (2009) investigated the efficiency of the bank credit channel in ten CEE countries in the period between 1999 and 2005 within the framework of a comparison model involving bank characteristics such as size and liquidity and summarized the prediction results as follows: the bank credit channel would be strengthened more in the future.

Egert and MacDonald (2009) evaluated the developments in the monetary transmission mechanism in all EU member CEE countries for the period between 1993 and 2008 and observed that the efficiency of the exchange rate channel decreased gradually. They concluded that the asset prices channel was not efficient due to shallow stock exchange markets; and the credit channel was not efficient enough because the headquarters of the banks and companies in the countries were affected by the monetary policies in the Eurozone as they exposed to credit terms there.

Based on the above-mentioned studies in literature, the present study aims to make analyses including recent years and to contribute to evaluations about the relevant efficiency of the monetary transmission channels in CEE countries.

\section{DATASET AND ECONOMETRIC METHODOLOGY}

\subsection{Dataset}

The annual data related to the period from 1995:01 to 2012:12 2015/2 that were obtained from the databases of the World Bank and the International Monetary Fund (IMF) were used. The variables included in analyses were determined based on monetary transmission mechanism literature. In this regard, real interest rate (RIR) was used for representing the interest rate channel; exchange rate (ER) was used for representing the exchange rate channel; and loan rate (LR) was used for representing the credit channel. Financial development rate (FDR), which refers to the share of M2money supply amount in GDP that is one of the most frequently used financial development 
indicators, was used for representing the financial development channel. Moreover, gross domestic product (GDP) and consumer price index (CPI) representing inflation were used as macroeconomic variables in the models. Table 1 given in the Appendix 1 presents the sources and explanations of the variables used in the models.

\subsection{Econometric Methodology}

\subsubsection{Short-term Analysis through VAR Method}

The short-term dynamics of the responses of the variables representing transmission channels to macroeconomic variables such as inflation and GDP in CEE countries were determined via VAR method. Eviews 8.0 was used in analysis.

The feedback effect ${ }^{1}$ must be taken into consideration in order to determine the influences of the transmission channels on inflation and GDP. The use of VAR models that take into account the feedback effect and impulse response functions is considered more convenient in comparison to the use of other analysis types. Impulse response functions play an important role in reflecting the impact of a one-standard deviation shock in any one of random error terms on the current and the future values of endogenous variables and in determining the interaction between the variables (Özgen and Güloğlu, 2004, p. 103). In this way, impulse response functions allow determining whether or not the variable (among variables representing the monetary transmission channels) found to be influential on inflation and GDP monetary transmission can be used as a policy tool.

As the series used in VAR models have to be stationary, standard generalized Dickey-Fuller (ADF) unit root test was carried out to determine whether or not the data series were stationary in the first place. Then the results were estimated through equation 1 .

Inquipy

$2015 / 2$

$Z_{t}=\alpha_{1} Z_{t-1}+\alpha_{2} Z_{t-2}+\beta+\ldots+\alpha_{n} Z_{t-n}+\beta X_{t}+\varepsilon_{t}$

In the equation $1, \mathrm{Z}$ refers to the vector of $\mathrm{n}$ variables; $\mathrm{X}$ refers to the deterministic variable vector; and $\varepsilon$ refers to the error term. Based on the equation 1, 80 different VAR models were created

\footnotetext{
${ }^{3}$ The feedback effect means that a change occurring in a variable influential on the monetary transmission channels may affect not only the real economy but also the future values of other variables that influence transmission channels (Huseynov and Jamilov, 2013, pp. 18-19).
} 
in order to determine short-term coefficients pertaining to the influence of each monetary transmission channel on inflation and GDP in the countries examined. The appropriate amount of delay was determined, and an attempt was made to calculate the quantity of the influences of the monetary transmission channels on inflation and GDP via impulse response functions. In the models established, the validation of certain assumptions (e.g. non-existence of serial correlation and autocorrelation and having a normal distribution) was tested firstly. Monte Carlo technique was used for calculating standard errors related to impulse response functions (for detailed information, see. Hamilton, 1994, p. 323).

\subsubsection{Long-term Analysis through ARDL Method}

The long-term relationships between the variables representing the monetary transmission channels and inflation and GDP in CEE countries were determined through ARDL method via Microfit 5.0. Developed by Pesaran et al. in 2001, ARDL method was used because it eliminates problems such as the endogeneity of the variables used in models, failure in testing the hypotheses formulated in regard to the coefficients estimated, and smallness of the sample (Narayan, 2004, pp. 351-354). Another important reason for the use of ARDL method in the present study is that it ignores the stationarity testing of the variables. As a matter of fact, some variables used in the models concerning the monetary transmission channels were not stationary at level. In the present study, 80 different ADRL models were established in order to determine the long-term coefficients concerning the influence of each monetary transmission channel on inflation and GDP in the countries examined. Equation 2 and equation 3 show the long-term relationships between the interest rate channel, which is one of the monetary transmission channels, and Inquiry inflation and GDP.

2015/2

$$
\begin{aligned}
& C P I_{i, t}=\alpha_{0}+\sum_{j=1}^{m} \alpha_{1 i} \Delta C P I_{i, t-j}+\sum_{j=0}^{m} \alpha_{2 i} \Delta R I R_{i, t-j}+\alpha_{3} C P I_{i, t-1} \\
& +\alpha_{5} R I R_{i, t-1}+v_{t}(2) \\
& \operatorname{lnGDP} P_{i, t}=\alpha_{0}+\sum_{j=1}^{m} \alpha_{1 i} \Delta \operatorname{lnGDP_{i,t-j}},+\sum_{j=0}^{m} \alpha_{2 i} \Delta R I R_{i, t-j}+\alpha_{3} \operatorname{lnGDP_{i,t-1}} \\
& +\alpha_{4} R I R_{i, t-1}+v_{t}(3)
\end{aligned}
$$


$m$ included in the equation 2 and the equation 3 refers to the length of delay. $\mathrm{CPI}_{\mathrm{i}, \mathrm{t}}$ shows the inflation of countryi at time $t$. $\ln \mathrm{GDP}_{\mathrm{i}, \mathrm{t}}$ refers to the GDP value of country iat time $t$. RIR ${ }_{i, t}$ indicates the real interest rate of country iat time $t$.

Though there is no need to do stationarity testing for the variables used in models in ARDL method, the cointegration test indicating a long-term relationship has to be carried out. The cointegration test is carried out through an F test in ARDL method. In the F test, while the null hypothesis if formulated to claim "there is not cointegration", the alternative hypothesis is formulated to claim "there is cointegration". When the F statistical value gets a value over the upper critical level, the null hypothesis is rejected, and it is concluded that there is cointegration. When the $\mathrm{F}$ statistical value gets a value below the lower critical value, on the other hand, the null hypothesis is not rejected, and it is concluded that there is not cointegration. If the F statistical value gets a value between the upper and the lower critical values, neither of the hypotheses can be rejected, and no conclusion is drawn about cointegration (Kremers, Ericsson, and Dolado 1992, p. 328).

\subsection{Analysis Results}

\subsubsection{Short-term Analysis Results}

In the present study, an attempt was made to explain the shortterm dynamics of the influences of each variable representing the monetary transmission channels on macroeconomic variables such as inflation and GDP by use of impulse response functions given in the figures 1 to 4 in the Appendix 2. Based on the figures, the interest rate, exchange rate, credit, and financial development channels were seen to be more influential on inflation in comparison to GDP. The short-term analysis results concerning each channel are provided below.

\section{- The Interest Rate Channel}

The real interest rate was used as the main policy variable representing the interest rate channel in order to investigate the efficiency of the channel. The Figure 1 given in the Appendix 2 demonstrates the responses of inflation and GDP to a one-standard 
deviation shock created in the real interest rate through impulse response functions on the country basis. It is seen that while the countries where the interest rate channel is influential on inflation are Estonia, Slovakia, Latvia, and Slovenia, the countries where the interest rate channel is influential on GDP are Romania, Slovakia, and Latvia.

\section{- The Exchange Rate Channel}

Exchange rate was used as the main policyvariable representing the exchange rate channel in order to investigate the efficiency of the channel. The Figure 2 given in the Appendix 2 demonstrates the responses of inflation and GDP to a one-standard deviation shock created in the exchange rate through impulse response functions on the country basis. It is seen that while the countries where the exchange rate channel is influential on inflation are Lithuania, Hungary, Romania, the Czech Republic, Slovenia, and Slovakia, the countries where the exchange rate channel is influential on GDP are Slovenia, Estonia, Lithuania, and Latvia.

\section{- The Credit Channel}

Loan rate was used as the main policy variable representing the credit channel in order to investigate the efficiency of the channel. The Figure 3 given in the Appendix 2 demonstrates the responses of inflation and GDP to a one-standard deviation shock created in the loan rate through impulse response functions on the country basis. It is seen that while the countries where the credit channel is influential on inflation are Bulgaria, Slovenia, the Czech Republic, Hungary, and Poland, the countries where the exchange rate channel is influential on GDP are Estonia, the Czech Republic, and Hungary.

\section{- The Financial Development Channel}

The financial development rate was used as the main policy variable representing the financial development channel in order to investigate the efficiency of the channel. The Figure 4 given in the Appendix 2 demonstrates the responses of inflation and GDP to a one-standard deviation shock created in the financial development rate through impulse response functions on the country basis. It is seen that while the countries where the financial development channel 
is influential on inflation are Bulgaria, Slovenia, Lithuania, Hungary, Slovakia, and Latvia, the countries where the financial development rate channel is influential on GDP are Bulgaria, Slovenia, Estonia, Lithuania, and Latvia.

\subsubsection{Long-term Analysis Results}

Table 3 given in the Appendix 4 shows the cointegration results regarding the existence of long-term relationship between the variables representing the monetary transmission channels and inflation and GDP. Table 4 included in the Appendix 5 shows the analysis results about the influences of these variables on inflation and GDP in the long-term obtained through ARDL method on the country basis. The long-term analysis results concerning each channel are summarized below. The statistically significant relationships between the variables representing the transmission channels and the macroeconomic variables included in the study demonstrate that the transmission channels are influential on inflation and GDP in the countries examined.

\section{- The Interest Rate Channel}

A statistically significant relationship was found between the real interest rate representing the interest rate channel and inflation in Bulgaria, Romania, Lithuania, and Latvia in the long-term. The relationship between the real interest rate and inflation was positive and statistically significant at \%1 significance level in Romania and Latvia and at 5\% significance level in Lithuania. Such relationship was negative and statistically significant at $1 \%$ significance level. In other words, an increase in the interest rate led to an increase in inflation in Romania, Lithuania, and Latvia and a decrease in inflation in Bulgaria in the long term. A statistically significant relationship was found between the real interest rate and GDP in Bulgaria, Lithuania, Latvia, Poland, and Estonia. The relationship between the real interest rate and GDP was negative and statistically significant at $\% 1$ significance level in Bulgaria, Lithuania, Latvia, and Estonia and at 5\% significance level in Poland. In other words, an increase in the interest rate led to a decrease in GDP in the long term.

Inquipy 2015/2 


\section{- The Exchange Rate Channel}

A statistically significant relationship was found between the exchange rate representing the exchange rate channel and inflation in Bulgaria, Slovenia, Hungary, Romania, Latvia, and Poland in the long-term. The relationship between the exchange rate and inflation was statistically significant at \%1 significance level inBulgaria, Slovenia, Hungary, Romania, and Poland and at 5\% significance level in Latvia. It was positive in Bulgaria, Slovenia, Hungary, Romania, and Poland and negative in Latvia. Non-determination of any statistically significant relationship between the exchange rate and inflation in Slovakia, Lithuania, the Czech Republic, and Estonia shows that the exchange rate channel was not influential on inflation in these countries in the long term. On the other hand, a statistically significant relationship was found between the exchange rate channel and GDP in Slovakia, Poland, and Slovenia at 1\%,5\%, and 10\% significance levels respectively. The relationship between the real interest rate and GDP was negative in Slovakia and Poland and positive in Slovenia.

\section{- The Credit Channel}

A statistically significant relationship was found between the loan rate representing the credit channel and inflation in Slovenia, Slovakia, Lithuania, and Estonia in the long-term. The relationship between the loan rate and inflation was statistically significant at \%1 significance level in Lithuania and at 5\% significance level in Slovenia, Slovakia, and Estonia. It was negative in Slovakia but positive in Slovenia, Lithuania, and Estonia. On the other hand, a statistically significant relationship was found between the loan rate channel and GDP in Bulgaria, Hungary, Romania, Lithuania, the Czech Republic, and Estonia. Such relationship was negative and statistically significant

Inquipy $2015 / 2$ at $1 \%$ significance lvel in Hungary, Romania, the Czech Republic, and Estonia, at 5\% significance level in Lithuania, and at 10\% significance level in Bulgaria respectively.

\section{- The Financial Development Channel}

A statistically significant relationship was found between the financial development rate representing the financial development channel and inflation in Bulgaria, Hungary, Lithuania, Latvia, Poland, the Czech Republic, and Estonia in the long-term. The relationship 
between the financial development rate and inflation was statistically significant at \%1 significance level in Bulgaria, Hungary, Lithuania, Latvia, and Poland and at 5\% significance level in the Czech Republic and Estonia. It was positive in Bulgaria, Hungary, Lithuania, Latvia, Poland, and the Czech Republic but negative in Estonia. On the other hand, a statistically significant positive relationship was found between the financial development rate channel and GDP in Bulgaria, Lithuania, Latvia, and Estonia. The relationship was statistically significant at $1 \%$ significance level in these countries.

\section{CONCLUSION}

This study investigated the short-term and the long-term influences of the variables representing the monetary transmission channels on inflation and GDP in order to determine the efficiency of the monetary transmission channels in CEE transition economies. The analysis results are summarized below.

The evaluation based on the implemented monetary policy strategies shows the following for the economies implementing inflation targeting: the exchange rate and the credit channels are influential on inflation in the short term and the financial development channel is influential on inflation in the long-term while the credit channel is influential on GDP both in the short term and in the long term in the Czech Republic (1997); the credit channel is influential on inflation in the short term and the exchange rate and the financial development channels are influential on inflation in the long term while no transmission channel is influential on GDP in the short term, and the exchange rate is influential on GDP in the long term in Poland (1998); the credit channel is influential on inflation in the short term and the financial development and the exchange rate channels are influential on inflation both in the short term and in the long term while the credit channel is influential on GDP both in the short term and in the long term in Hungary (2001); and the exchange rate is influential on inflation in the short term and in the long term while the interest rate is influential on GDP in the short term, and the credit channel is influential on GDP in the long term in Romania (2005).

The evaluation based on the implemented monetary policy strategies shows the following for the economies implementing 
exchange rate targeting: the credit and the financial development channels are influential on inflation and GDP in the long term in Estonia (1992); the financial development is influential on inflation and GDP both in the short term and in the long term while the exchange rate channel is influential on inflation and GDP in the short term, and the interest rate and credit channels are influential on inflation and GDP in the long term in Lithuania (1994); and the financial development channel is influential on inflation and GDP in the short term and in the long term while the interest rate channel is influential on inflation and GDP in the long term in Bulgaria (1997).

The evaluation for the countries in the Eurozone indicates the following; the interest rate and the financial development channels are influential on inflation and GDP both in the short term and in the long term while the interest rate channel and the exchange rate channel are influential on inflation and GDP in the short term in Latvia; the interest rate is influential on inflation and GDP in the short term in Slovakia; the exchange rate channel is influential on inflation and GDP both in the short term and in the long term in Slovenia while the financial development channel is influential on inflation and GDP in the short term.

In regard to the interest rate, exchange rate, and credit channels, the results of the present study are generally parallel with the results of Ganev et al. (2002), Creel and Levasseur (2005), and Oros and Romocea-Turcu (2009).

In the present study, the evaluation about the direction of the influences on the basis of country through ARDL analysis yielded results consistent with the theory in general.

It is seen that there is a statistically significant positive relationship between the real interest rate and inflation, and an increase occurring in the interest rate (financing cost), through cost inflation, may cause an increase in the inflation rate in the long term in Romania. On the other hand, there is a statistically significant negative relationship between the real interest rate and inflation, and an increase occurring in the interest rate, through demand inflation, may cause a decrease in the inflation rate in Bulgaria. 
To the contrary of the statistically significant positive relationship between the exchange rate and inflation in Bulgaria, Slovenia, Hungary, Romania, and Poland, the significant negative relationship between the exchange rate and inflation in Latvia implies deflationary and inflationary spirals as a result of pass-through.

The statistically significant negative relationship between the loan rate and GDP in Bulgaria, Hungary, Romania, Lithuania, the Czech Republic, and Estonia may be regarded as an increase in investments and total product as a result of increase in loans because of decrease in the loan rate.

The relationship between the financial development rate and inflation may have been found statistically significant and positive in Bulgaria, Hungary, Lithuania, Latvia, Poland, andthe Czech Republic in the present study because the share of M2 money supply in GDP was used as the indicator of the financial development level. It is known that most economists have the idea, based on the monetarist approach, that increase in money supply has a long-term influence on the general level of prices. The statistically significant positive relationship between the financial development rate and GDP in Bulgaria, Lithuania, Latvia,andEstonia may imply that increase in investments will lead to an increase in product in the economies having a developed financial sector as a result of the increase in the funding possibilities of the real sector.

Based on the results of the present study, it can be concluded that the financial development channel and the exchange rate channel are the channels most influential on inflation and GDP in CEE transition economies in the short term and in the long term and these channels are followed by the credit and interest rate channels, and the transition economies where the transmission channels function most efficiently are Lithuania and Latvia. The efficiency of the financial development channel may bring a big advantage to the countries which aim to join the Eurozone because monetary targeting plays an active role in ensuring price stability, and the European Central Bank implements the monetary targeting strategy. Thus, monetary policy decision-makers of the economies subject to analysis should give priority to raising financial development levels and use the exchange rate as a monetary policy tool in accomplishing the targets of price stability and increased GDP that may contradict with one another. 


\section{REFERENCES}

Anzuini, A. and Levy, A. (2007). "Monetary policy shocks in the new EU members: A VAR approach". Applied Economics, 39 (9), 1147-1161.

Bernanke, B. S. and Gertler, M. (1995). "Inside the black box: The credit channel of monetary policy transmission". Journal of Economic Perspectives, 9 (4), 27-48.

Creel, J. and Levasseur, S. (2005). "Monetary policy transmission mechanisms in the CEECs: How important are the differences with the euro area?". Document de Travail, Paris: Observatoire Francais des Conjonctures Economiques (OFCE).

Dornbusch, R, Fischer S. (1994). Macroeconomics. 5th ed., New York: McGraw Hill.

Égert, B. and MacDonald R. (2009). "Monetary transmission mechanism in central and eastern europe: surveying the surveyable". Journal of Economic Surveys, 23 (2), 277-327.

Elbourne, A. and de Haan J. (2006). "Financial structure and monetary policy transmission in transition countries". Journal of Comparative Economics, 34 (1), $1-23$.

Faini, R. and de Melo, J. (1990). "Adjustment, investment, and the real exchange rate in developing countries". Economic Policy, 5 (11), 491-519.

Fraga, A., GoldfajnI. and MinellaA. (2003). "Inflation targeting in emerging market economies”. NBER Macroeconomics Annual, (18), 365-416.

Ganev, G. Y., Molnar, K., Rybinski, K. and Wozniak, P.(2002). "Transmission mechanism of monetary policy in Central and Eastern Europe". Raporty Case (52), Warsaw, Poland: Center for Social and Economic Research.

Hamilton, J. D. (1994). Time series analysis (2). Princeton: Princeton University Press.

Hericourt J. and Matei, I. (2006). "Transmission de la politique monétaire dans les Pays d'Europe Centrale et Orientale: Que savons-nous vraiment?". Economie et Prévision, 180 (180-181), 221-238.

Huseynov,E. and Jamilov, R. (2013). "Channels of monetary transmission in the CIS: A review". Journal of Economic and Social Studies, 3 (1), 5-61.

IMF. Data and Statistics. <http://elibrary-data.imf.org/>(08.07.2014).

Jarocinski, M. (2004). "Responses to monetary policy shocks in the East and the West of Europe. A comparison". Network Studies and Analyses (287), Warsaw, Poland: Center for Social and Economic Research.

Jimborean, R. (2009). "The role of banks in the monetary policy transmission in the new EU member states”. Economic Systems, 33 (4), 360-375 
Kremers, J. J., Ericsson, N. R. and Dolado, J. J. (1992). “The power of cointegration tests". Oxford Bulletin of Economics and Statistics, 54 (3), 325-348.

Kuttner, K. N. and Mosser, P. C. (2002). "The monetary transmission mechanism: Some answers and further questions". Federal Reserve Bank of New YorkEconomic Policy Review, 15-26.

Landry, A. (2009). "Expectations and exchange rate dynamics: A state-dependent pricing approach". Journal of International Economics, 78 (1), 60-71.

Matousek, R. and Sarantis, N. (2009). “The bank lending channel and monetary transmission in Central and Eastern European countries". Journal of Comparative Economics, 37 (2), 321-334.

Mishkin, F. S. (2007). The Economics of Money, Banking and Financial Markets. 8th Edition, Boston:Published by Pearson.

Narayan, P. K. (2004). "New Zealand's trade balance: evidence of the J-curve and Granger causality”. Applied Economics Letters, 11 (6), 351-354.

Oros, C. and Romocea-Turcu, C. (2009). "The monetary transmission mechanisms in the CEECs: A structural VAR approach". Applied Econometrics and International Development, 9 (2), 73-97.

Özgen, F. B. ve Güloğlu, B. (2004). “Türkiye’de iç borçların iktisadi etkilerinin VAR tekniğiyle analizi”. ODTÜ Gelişme Dergisi, 31 (1), 1-27.

Öztürk, N., Barışık, S. ve Darıcı, H. K. (2010). "Gelişmekte olan piyasalarda finansal derinleşme ve büyüme ilişkisi: Panel veri analizi”. ZKÜ Sosyal Bilimler Dergisi, 6 (12), 95-119.

Papadamou, S. and Oikonomou G. (2007). "The monetary transmission mechanism: Evidence from eight economies in transition". International Economic Journal, 21, (4), $559-76$.

Pesaran, M. H., Shin, Y. and Smith, R. J. (2001). "Bounds testing approaches to the analysis of level relationships”. Journal of Applied Econometrics, 16 (3), 289-326.

Sandte, H. (1999). "Moderate inflation, wirtschaftswachstum und geldpolitik, eine theoretische und empirische analyse". Veröffentlichungen des Instituts für Empirische Wirtschaftsforschung, Band 37, Berlin: Duncker und Humblot

Sariipek D. B. ve Kesici, M. R. (2010). "Yeni Keynesyen iktisat ve emek piyasaları". Paradoks Ekonomi, Sosyoloji ve Politika Dergisi,6 (2) 17-38.

Stone, M. R. (2003). “Greater monetary policy transparency for the G3: Lessons from full-fledged inflation targeters”. IMF Working Paper, 03/218, 1-26.

Svejnar, J. (2002). “Transition economies: Performance and challenges”. The Journal of Economic Perspectives, 16 (1), 3-28. 
Tanrı̈̈ver B. ve Yamak N. (2012). "Parasal şokların asimetrik etkileri: Teori ve Türkiye uygulaması”. Ege Akademik Bakış,12 (3), 339-350.

Taylor, J. B. (1993). Macroeconomic policy in a world economy, from econometric design to practical operation, Norton, New York.

Taylor, J. B. (1995). "The monetary transmission mechanism: An empirical framework". Journal of Economic Perspectives, 9 (4), 11-26.

Taylor, J. B. (1999). "Staggered price and wage setting in macroeconomics". Handbook of Macroeconomics, 1 (B), 1009-1050.

Türkiye Cumhuriyet Merkez Bankası. (2013). Parasal aktarım mekanizması. Ankara World Data Bank, (http:// http://databank.worldbank.org/ erişim tarihi:13.07.2014)

\section{Appendix 1}

Table 1: Data Set

\begin{tabular}{|l|l|l|}
\hline Variables & $\begin{array}{l}\text { Source and } \\
\text { Descriptions }\end{array}$ & Transmissions Channel \\
\hline $\begin{array}{l}\text { Consumer Price Index } \\
\text { (CPI) }\end{array}$ & $\begin{array}{l}\text { Source: World Bank } \\
\text { Format: 2010=100; } \\
\text { AnnualAvarege(\%) }\end{array}$ & \multirow{2}{*}{ Macroekonomic Variable } \\
\cline { 1 - 2 } $\begin{array}{l}\text { GrossDomestic Product } \\
\text { (GDP) }\end{array}$ & $\begin{array}{l}\text { Source : World Bank } \\
\text { Format: 2005 constant; } \\
\text { LocalCurrency; } \\
\text { Logaritmic Form }\end{array}$ & \\
\hline $\begin{array}{l}\text { Real Interest Rate } \\
\text { (RIR) }\end{array}$ & $\begin{array}{l}\text { Source : World Bank } \\
\text { Format: End of theYear } \\
\text { (\%) }\end{array}$ & Real Interest Rate \\
\hline $\begin{array}{l}\text { Exchange Rate } \\
\text { (ER) }\end{array}$ & $\begin{array}{l}\text { Source : World Bank } \\
\text { Format: End of theYear; } \\
\text { Logaritmic Form }\end{array}$ & Exchange Rate \\
\hline $\begin{array}{l}\text { Credit Rate } \\
\text { (LR) }\end{array}$ & $\begin{array}{l}\text { Source : IMF } \\
\text { Format: End of theYear, } \\
\text { Avarage Lending Rate }\end{array}$ & Credit \\
\hline $\begin{array}{l}\text { Financial Development } \\
\text { Rate } \\
\text { (FDR) }\end{array}$ & $\begin{array}{l}\text { Source : World Bank } \\
\text { Format: M2Money } \\
\text { Supply/GDP; Nominal; } \\
\text { End of theYear; } \\
\text { Logaritmic Form }\end{array}$ & Financial Development \\
\hline
\end{tabular}


The Effectiveness of Monetary Transmission Channels
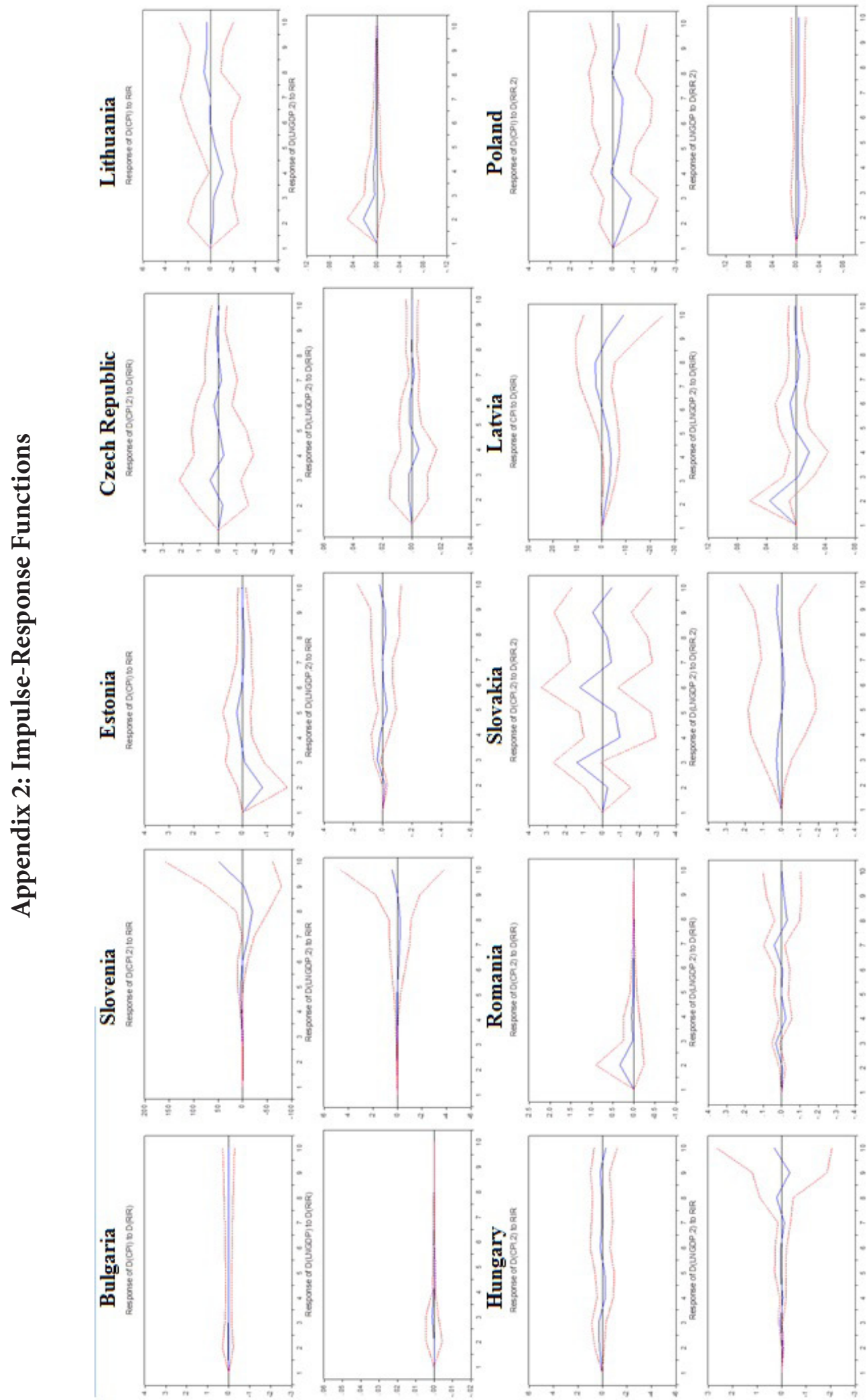

تี 
F. G. Odabaşıoğlu, C. Aydın
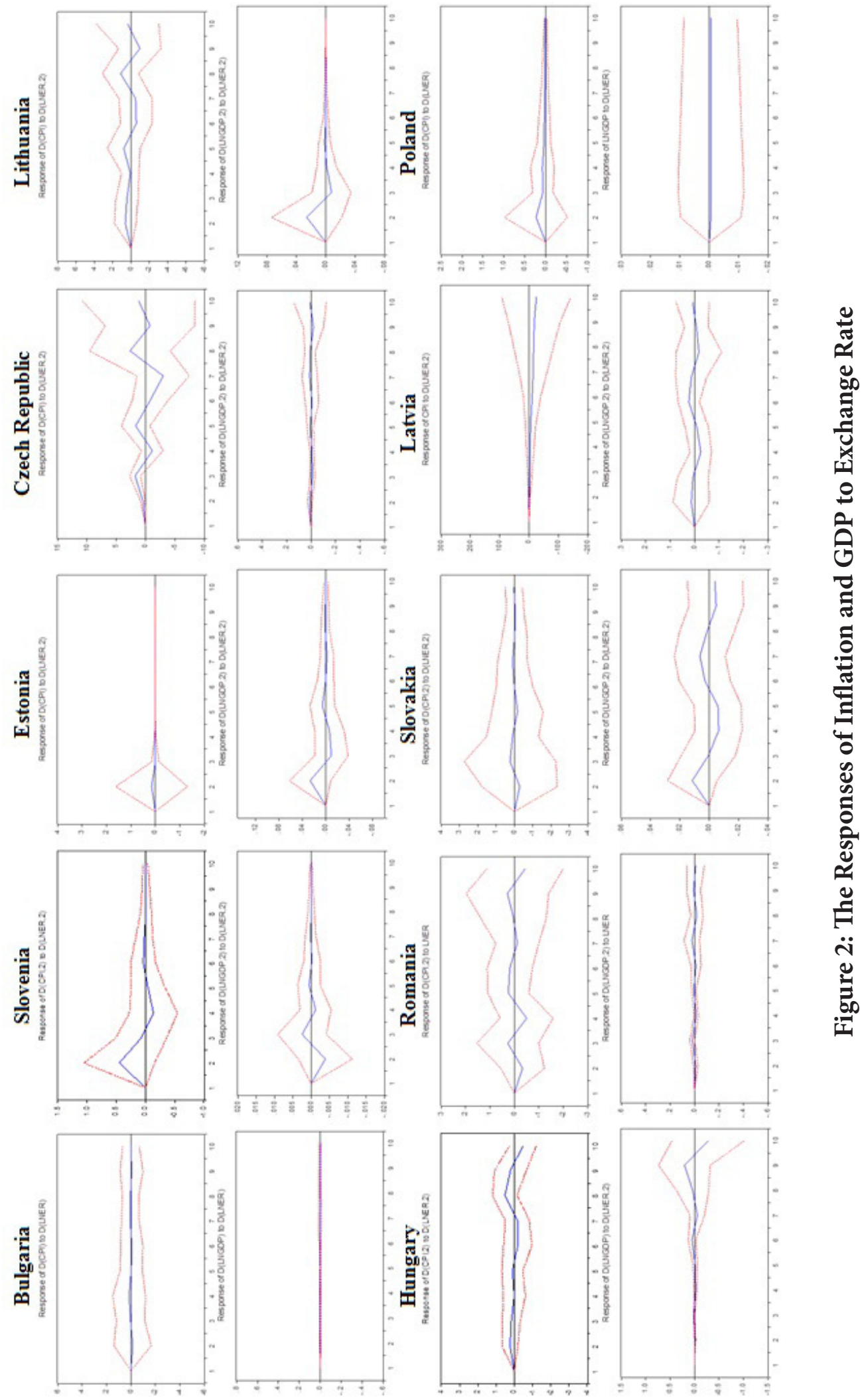
The Effectiveness of Monetary Transmission Channels
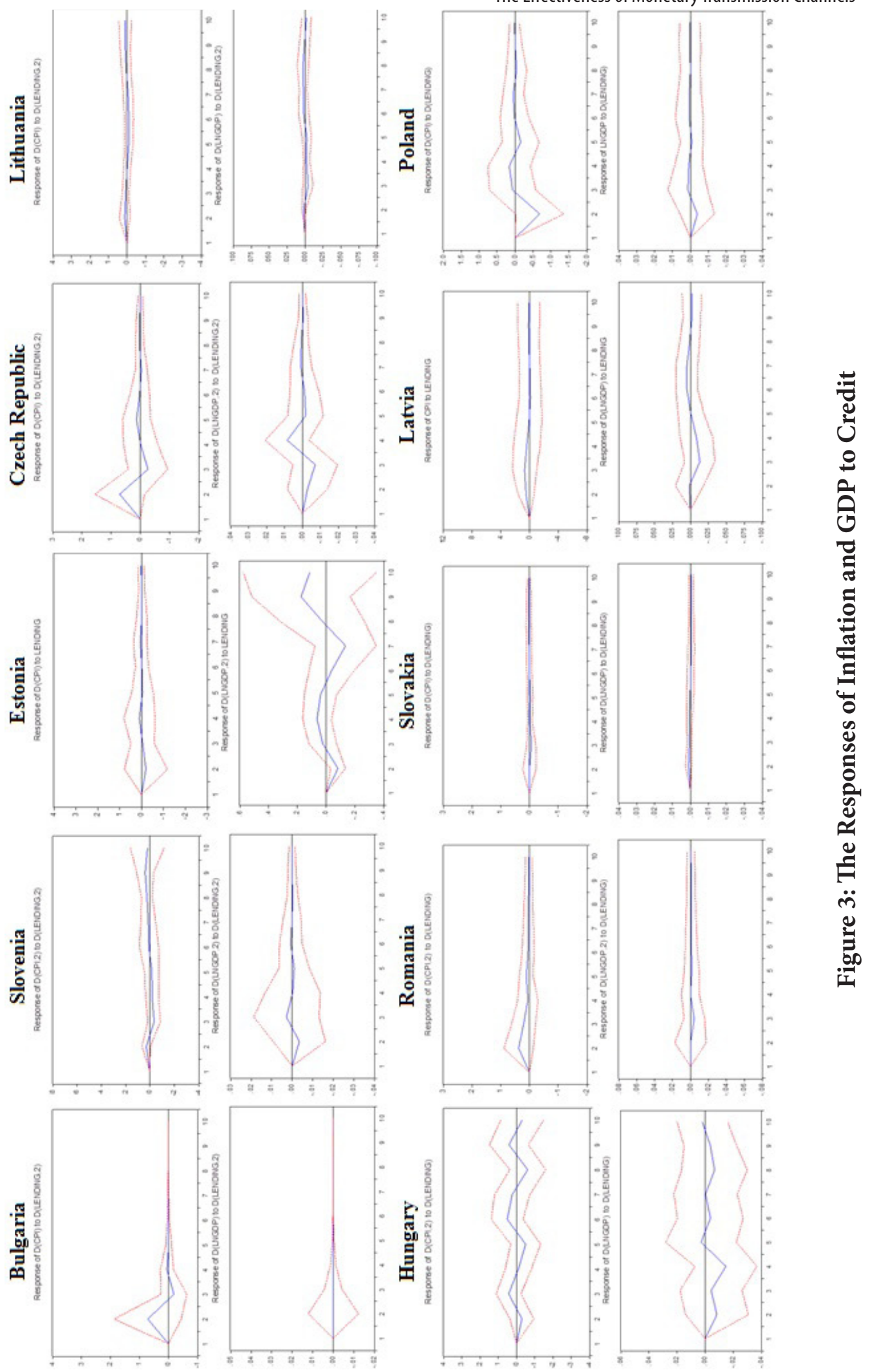
F. G. Odabaşıoğlu, C. Aydın
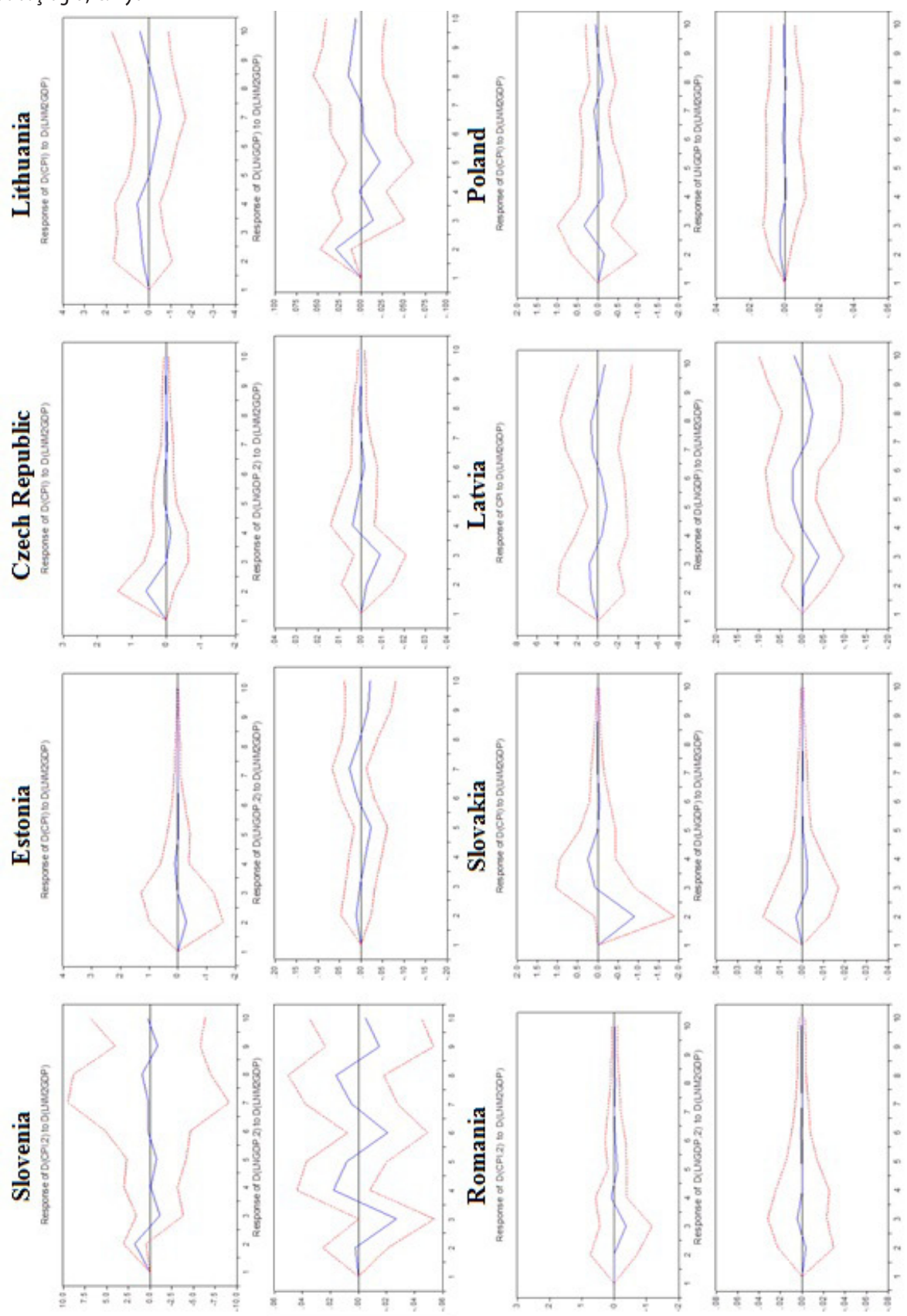

䒕
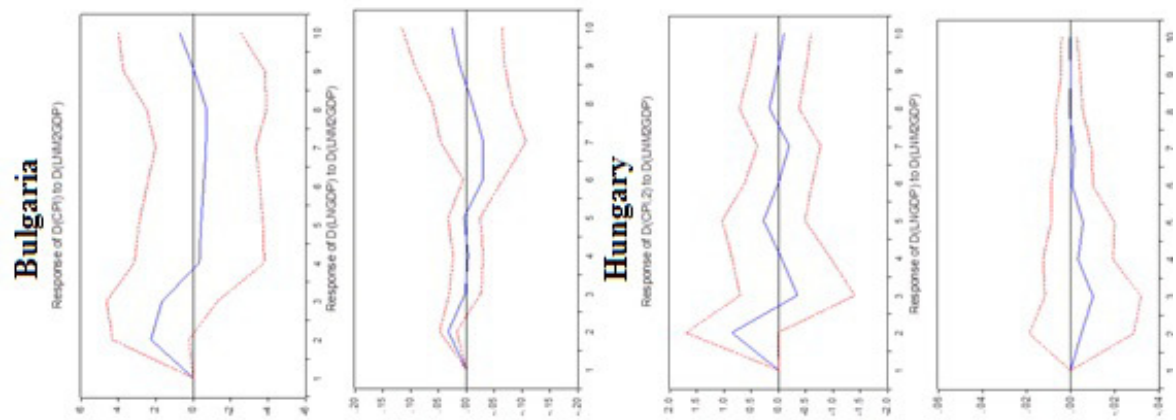


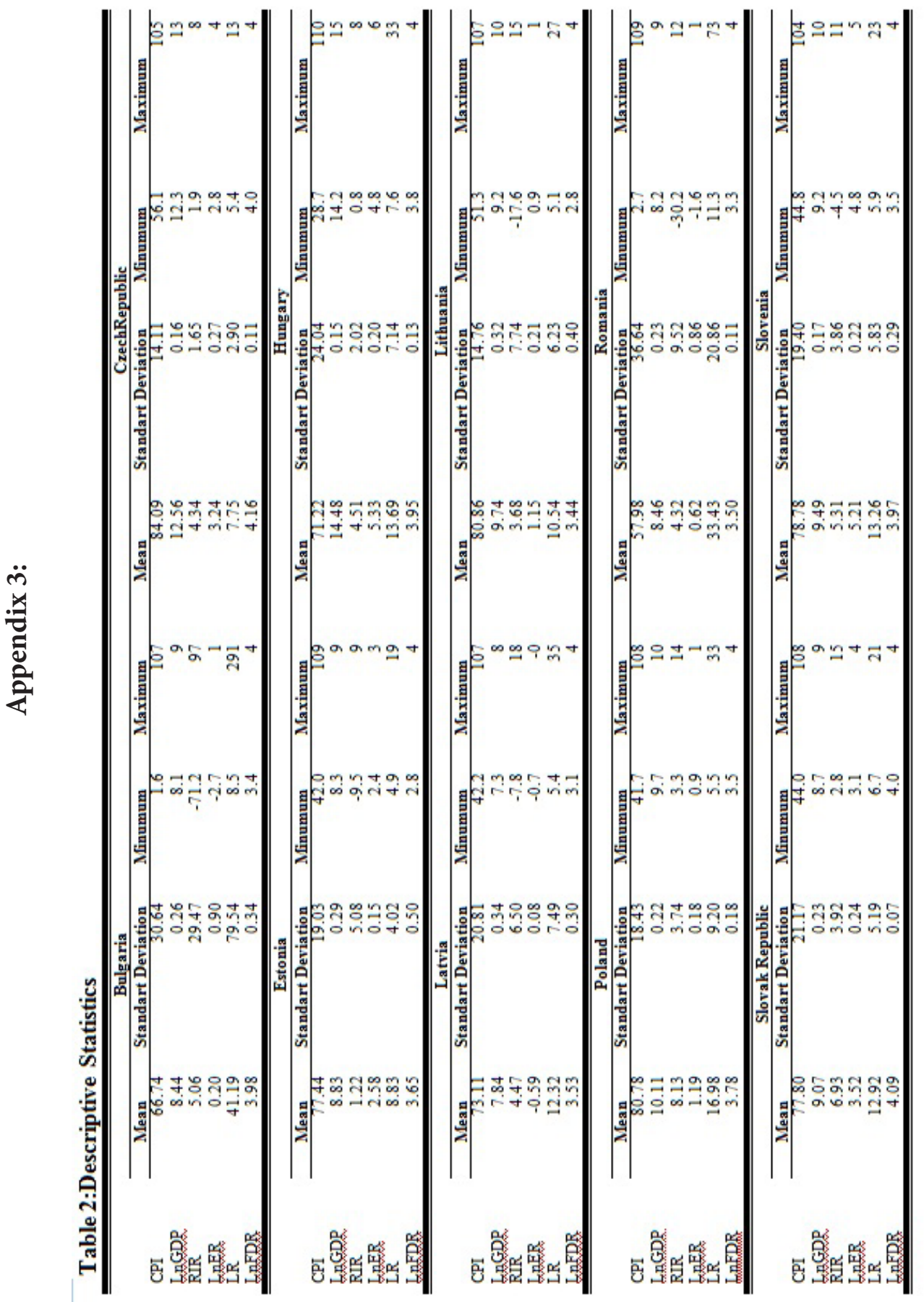




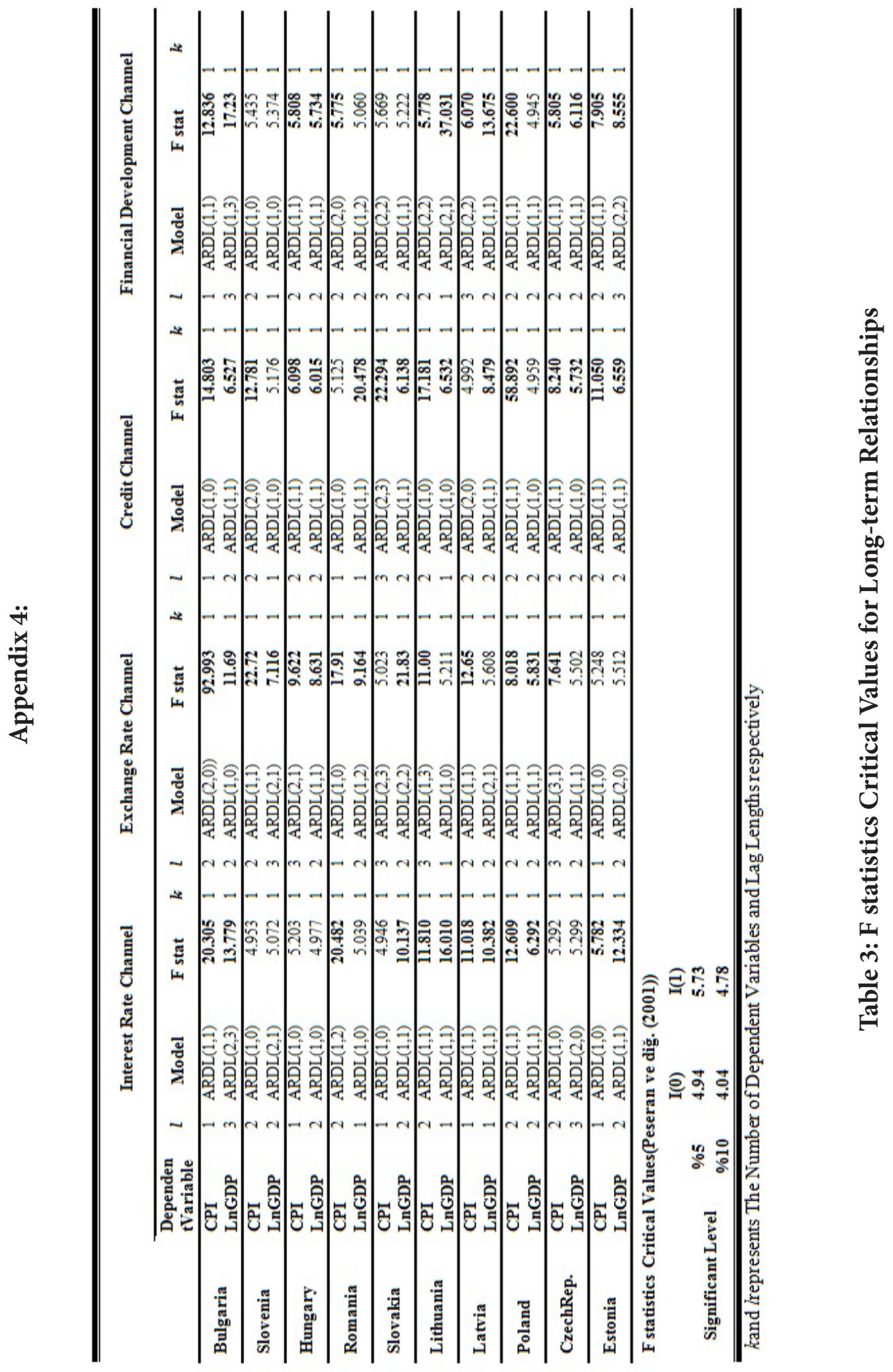




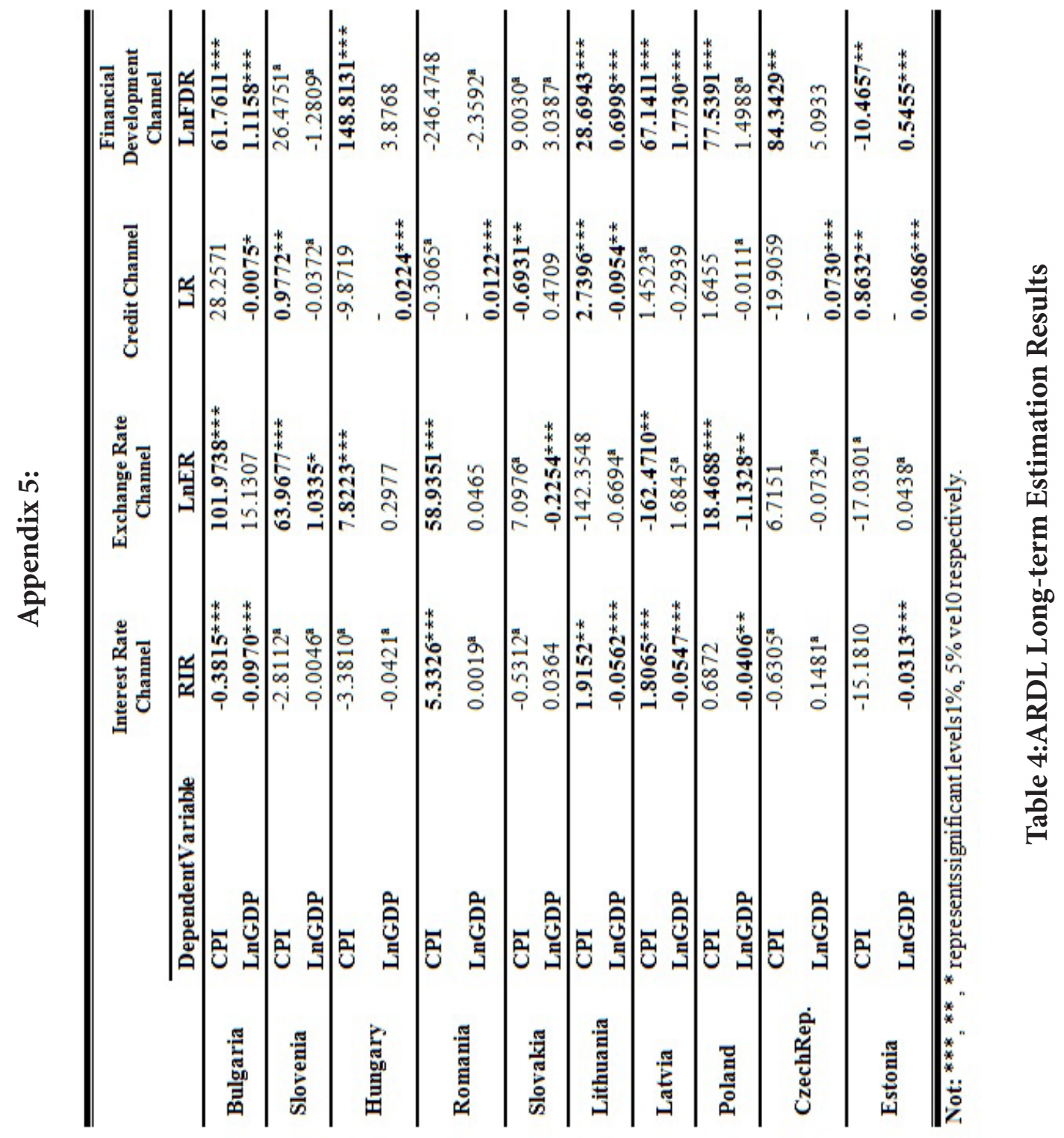


